\title{
PERBANDINGAN SK DAN KD PADA STANDAR ISI KURIKULUM 2006 DENGAN KI DAN KD PADA STANDAR ISI KURIKULUM 2013 MATA PELAJARAN BAHASA INDONESIA SMA KELAS XI DILIHAT DARI TAKSONOMI TUJUAN PEMBELAJARAN, CAKUPAN KETERAMPILAN BERBAHASA, ILMU KEBAHASAAN DAN ILMU KESASTRAAN
}

\author{
Aan Sugiantomas, Asep Jejen Jaelani, \& Ria Handayani \\ Pendidikan Bahasa dan Sastra Indonesia Universitas Kuningan \\ Jalan Cut Nyak Dien no. 36 Kuningan Jawa Barat
}

\begin{abstract}
Abstrak
Judul penelitian ini adalah Perbandingan SK dan KD pada Standar Isi Kurikulum 2006 dengan KI dan KD pada Standar Isi Kurikulum 2013 Mata Pelajaran Bahasa Indonesia SMA Kelas XI Dilihat dari Taksonomi Tujuan Pembelajaran, Cakupan Keterampilan Berbahasa, Ilmu Kebahasaan dan Ilmu Kesastraan. Rumusan masalah : 1) bagaimana taksonomi tujuan pembelajaran pada SK dan KD dalam Standar Isi Kurikulum 2006 mata pelajaran Bahasa Indonesia SMA kelas XI?; 2) bagaimana taksonomi tujuan pembelajaran pada KI dan KD dalam Standar Isi Kurikulum 2013 mata pelajaran Bahasa Indonesia SMA kelas XI wajib?; 3) bagaimana perbandingan taksonomi tujuan pembelajaran pada SK dan KD dalam Standar Isi Kurikulum 2006 dengan KI dan KD pada Standar Isi Kurikulum 2013 mata pelajaran Bahasa Indonesia SMA kelas XI?; 4) bagaimana perbandingan SK dan KD dalam Standar Isi Kurikulum 2006 dengan KI dan KD dalam Standar Isi Kurikulum 2013 mata pelajaran Bahasa Indonesia SMA kelas XI dilihat dari cakupan Keterampilan Berbahasa?; 5) bagaimana perbandingan SK dan KD dalam Standar Isi Kurikulum 2006 dengan KI dan KD dalam Standar Isi Kurikulum 2013 mata pelajaran Bahasa Indonesia SMA kelas XI dilihat dari cakupan Ilmu Kebahasaan?; 6) bagaimana perband ingan SKKD dalam Standar Isi Kurikulum 2006 dengan KIKD dalam Standar isi kurikulum 2013 mata pelajaran Bahasa Indonesia SMA kelas XI dilihat dari cakupan ilmu kesastraan?. Penelitian ini be rtujuan untuk 1) mengetahui taksonomi tujuan pembelajaran pada SK dan KD dalam Standar Isi Kurikulum 2006 mata pelajaran Bahasa Indonesia SMA kelas XI, 2) mengetahui taksonomi tujuan pembelajaran pada KI dan KD dalam Standar Isi Kurikulum 2013 mata pelajaran Bahasa Indonesia SMA kelas XI wajib, 3) mengetahui perbandingan taksonomi tujuan pembelajaran pada SK dan KD dalam Standar Isi Kurikulum 2006 dengan KI dan KD pada Standar Isi Kurikulum 2013 mata pelajaran Bahasa Indonesia SMA kelas XI, 4) mengetahui perbandingan SK dan KD dalam Standar Isi Kurikulum 2006 dengan KI dan KD pada Standar Isi Kurikulum 2013 mata pelajaran Bahasa Indonesia SMA kelas XI wajib dilihat dari cakupan keterampilan berbahasa, 5) mengetahui perbandingan SK dan KD dalam Standar Isi Kurikulum 2006 dengan KI dan KD pada Standar Isi Kurikulum 2013 mata pelajaran Bahasa Indonesia SMA kelas XI wajib dilihat dari cakupan ilmu kebahasaan, 6) mengetahui perbandingan SK
\end{abstract}


dan KD dalam Standar Isi Kurikulum 2006 dengan KI dan KD pada Standar Isi Kurikulum 2013 mata pelajaran Bahasa Indonesia SMA kelas XI wajib dilihat dari cakupan ilmu kesastraan. Metode yang digunakan yaitu deskriptif kualitatif. Simpulan dalam penelitian ini yaitu taksonomi tujuan pembelajaran yang terdapat dalam SKKD Kurikulum 2006 ternyata lebih mendominasi pada ranah kognitif jenjang pemahaman (C2). Sedangkan Taksonomi Tujuan Pembelajaran yang terdapat dalam KIKD Kurikulum 2013 mata pelajaran bahasa Indonesia SMA kelas XI (wajib), ternyata lebih mendominasi pada ranah kognitif jenjang penerapan (C3). Maka dari itu, jika dibandingkan Taksonomi Tujuan Pembelajaran yang terdapat dala SKKD Kurikulum 2006 dengan KIKD Kurikulum 2013 ternyata sama-sama mendominasi kedalam ranah Kognitif, yang membedakan hanyalah jenjangnya saja. Cakupan keterampilan berbahasa dalam SKKD dan KIKD mata pelajaran bahasa Indonesia SMA kelas XI yang lebih mendominasi adalah keterampilan berbahasa berbicara dan menulis. Cakupan ilmu kebahasaan dalam SKKD mata pelajaran bahasa Indonesia SMA kelas XI yang lebih mendominasi adalah semantik, sementara KIKD mata pelajaran bahasa Indonesia SMA kelas XI wajib semua cakupan ilmu kebahasaan terealisasikan secara merata. Cakupan ilmu kesastraan dalam SKKD mata pelajaran bahasa Indonesia SMA kelas XI dan KIKD mata pelajaran bahasa Indonesia SMA kelas XI wajib, lebih dominan pada kesastraan drama (film/drama).

Kata kunci : perbandingan, taksonomi tujuan pembelajaran, keterampilan berbahasa, ilmu kebahasaan, ilmu kesastraan, mata pelajaran bahasa Indonesia SMA kelas XI, standar isi kurikulum 2006, standar isi kurikulum 2013.

\section{PENDAHULUAN}

Umumnya di Indonesia, perubahan kurikulum dilakukan enam tahun sekali. Perubahan kurikulum terjadi karena adanya ketidakpuasan atau kekurangan terhadap kurikulum sebelumnya. Selain itu perkembangan jaman juga sangat berpengaruh dalam perubahan kurikulum, karena kurikulum harus disesuaikan dengan perkembangan jaman saat ini. Menurut UU Nomor 20 Tahun 2003 Pasal 1 Ayat 19, Kurikulum merupakan seperangkat rencana dan pengaturan mengenai tujuan, isi dan bahan pelajaran serta cara yang digunakan sebagai pedoman penyelenggaraan kegiatan pembelajaran untuk mencapai tujuan pendidikan tertentu.

Seperti yang telah diketahui, kurikulum di Indonesia telah mengalami beberapa kali perubahan. Setelah sepuluh tahun sistem pendidikan di Indonesia menggunakan Kurikulum 1994, barulah pemerintah mengganti Kurikulum 1994 menjadi Kurikulum 2004 (KBK). Namun pergantian kurikulum tersebut tak bertahan lama, karena pemerintah kembali memunculkan kurikulum baru yaitu Kurikulum 2006 atau yang lebih dikenal dengan nama Kurikulum Tingkat Satuan Pend idikan (KTSP). 
Ternyata penerapan Kurikulum 2006 juga tidak bertahan lama, karena setelah itu pemerintah kembali menerapkan kurikulum baru yaitu Kurikulum 2013, yang telah di tetapkan oleh Mohamad Nuh ketika beliau menjabat sebagai Menteri Pend id ikan Nasional dan Kebudayaan di Indonesia pada tahun 2013.

Namun saat ini kurikulum di Indonesia sedang dalam kebimbangan, kare na telah diterapkan dua kurikulum sekaligus yaitu Kurikulum 2006 dan Kurikulum 2013. Penerapan dua kurikulum sekaligus ini bukanlah tanpa sebab, hal ini terjadi seiring dengan bergantinya Menteri Pendidikan Nasional dan Kebudayaan yang sebelumnya dijabat oleh Mohamad Nuh namun sekarang digantikan oleh Anis Baswedan.

Sebelumnya Kurikulum 2013 hanya diberlakukan di beberapa Sekolah yang ditunjuk sebagai sekolah ujicoba penerapan Kurikulum 2013 yang berlangsung sekitar 1 tahun lebih. Setelah dianggap ujicoba tersebut sukses, maka pada pertengahan tahun 2014 Kurikulum 2013 diterapkan di seluruh sekolah pada jenjang pendidikan seperti SD/SMP/SMA yang ada di Indonesia.

Namun hal tersebut tak bertahan lama, karena ketika Anis Baswedan menjabat sebagai Menteri Pendidikan Nasional dan Kebudayaan pada tahun 2015, penerapan Kurikulum 2013 yang sebelumnya sudah diterapkan selama kurang lebih satu semester di sekolah-sekolah yang bukan sekolah ujicoba, diberhentikan dan kembali menggunakan Kurikulum 2006. Sedangkan sekolah yang memang sebelumnya telah menggunakan Kurikulum 2013 lebih dari 1 tahun, maka tetap diperbolehkan untuk menggunakan Kurikulum 2013. Kedua kurikulum tersebut tentu memiliki karakteristik yang berbeda satu sama lain.

Tentunya perbedaan karakteristik kedua kurikulum tersebut sangat membingungkan dan berpengaruh terhadap penerapan pembelajaran di sekolahsekolah. Perbedaan yang paling utama dari kedua Kurikulum tersebut yaitu dilihat dari Standar Isi. Standar Isi Kurikulum 2013 terdapat Kompetensi Inti (KI) dan Kompetensi Dasar (KD) yang mencakup tentang bidang keilmuan apa yang akan diajarkan pada peserta didik berupa materi teks. Sedangkan dalam Standar Isi Kurikulum 2006 terdapat Standar Kompetensi (SK) dan Kompetensi Dasar (KD) yang mencakup tentang bidang keilmuan apa yang akan diajarkan pada peserta didik yang lebih mengarahkan pada keterampilan berbahasa.

Seperti yang telah disampaikan di atas, di dalam kurikulum terdapat Standar Isi yang diturunkan dari Standar Kompetensi Lulusan (SKL). Standar Isi tersebut berisikan SK - KD untuk kurikulum 2006 dan KI - KD untuk kurikulum 2013. SKL dan Standar isi tersebut tentunya harus mengacu pada tujuan pembelajaran atau lebih dikenal dengan nama Taksonomi Intruksional atau Taksonomi Tujuan Pembelajaran.

Dalam SK-KD serta KI-KD khususnya dalam SK-KD dan KI-KD Mata Pelajaran Bahasa Indonesia SMA Kelas XI, terdapat beberapa aspek yang berkaitan dengan tujuan pembelajaran diantaranya Kata Kerja Operasional. Jika dilihat dari Kurikulum sebelumnya yaitu kurikulum 1994 hingga Kurikulum 2006, kata kerja operasional yang digunakan masih berpedoman pada Taksonomi Tujuan 
Pembelajaran yang digolongkan dalam tiga klasifikasi umum atau ranah (domain), yaitu: (1) ranah kognitif, berkaitan dengan tujuan belajar yang berorientasi pada kemampuan berpikir; (2) ranah afektif berhubungan dengan perasaan, emosi, sistem nilai, dan sikap hati); dan (3) ranah psikomotor (berorientasi pada keterampilan motorik atau penggunaan otot kerangka).

Namun dalam kurikulum 2013, banyak orang yang meragukan bahwa kata kerja operasional yang ada dalam KI dan KD masih berpedoman pada Taksonomi Tujuan Pembelajaran. Hal tersebut muncul karena melihat mater pembelajaran yang dijabarkan dalam KI-KD Kurikulum 2013 hanya berorintasi pada 15 teks saja.

Terkait dengan perubahan Kurikulum KTSP yang digantikan oleh Kurikulum 2013, dalam Kurikulm 2013 Mata Pelajaran Bahasa Indonesia dalam KI dan KD terdapat pula tentang Keterampilan Berbahasa, Ilmu Kebahasaan, dan Ilmu Kesastraan yang tidak dapat terlepas dari Mata Pelajaran Bahasa Indonesia.

Namun, ketika penulis melihat dan membaca hasil penelitian mengenai Cakupan Keterampilan Berbahasa, Ilmu Kebahasaan, dan Ilmu Kesastraan dalam KI dan KD Pada Standar Isi SMA Kelas XI Kurikulum 2013 Mata Pelajaran Bahasa Indonesia Wajib dan Peminatan yang telah diteliti oleh Sri Wulan, Mahasiswa PBSI UNIKU tahun akademik 2014, ternyata pada KI dan KD dalam Standar Isi Kurikulum 2013 mata pelajaran Bahasa Indonesia SMA Kelas XI, tidak dituliskan secara jelas.

Berbeda dengan SK dan KD dalam Standar Isi Kurikulum 2006, yang sebelumnya juga telah diteliti oleh Ely Nuraliyah, Mahasiswa PBSI UNIKU tahun akademik 2012, tentang Analisis SK dan KD pada Standar Isi Mata Pelajaran Bahasa Indonesia di SMA Berdasarkan Keterampilan Berbahasa, Ilmu Kebahasaan, Dan Ilmu Kesastraan (Sebuah Analisis Isi SK dan KD Mendengarkan, Berbicara, Membaca, Dan Menulis). Dalam penelitian tersebut semua bidang ilmu yang berkaitan dengan keilmuan bahasa Indonesia dituliskan secara jelas.

Berlandaskan dari latar belakang masalah di atas, maka penulis merumuskan permasalahan sebagai berikut: 1) bagaimana taksonomi tujuan pembelajaran pada SK dan KD dalam Standar Isi Kurikulum 2006 mata pelajaran Bahasa Indonesia SMA kelas XI?; 2) bagaimana taksonomi tujuan pembelajaran pada KI dan KD dalam Standar Isi Kurikulum 2013 mata pelajaran Bahasa Indonesia SMA kelas XI Wajib?; 3) bagaimana perbandingan taksonomi tujuan pembelajaran pada SK dan KD dalam Standar Isi Kurikulum 2006 dengan KI dan KD dalam Standar Isi Kurikulum 2013 mata pelajaran Bahasa Indonesia SMA kelas XI?; 4) bagaimana perbandingan SK dan KD dalam Standar Isi Kurikulum 2006 dengan KI dan KD dalam Standar Isi Kurikulum 2013 mata pelajaran Bahasa Indonesia SMA kelas XI dilihat dari cakupan keterampilan berbahasa?; 5) bagaimana perbandingan SK dan KD dalam Standar Isi Kurikulum 2006 dengan KI dan KD dalam Standar Isi Kurikulum 2013 mata pelajaran Bahasa Indonesia SMA kelas XI dilihat dari cakupan ilmu kebahasaan?; 6) bagaimana perbandingan SK dan KD dalam Standar Isi Kurikulum 2006 dengan KI dan KD dalam Standar Isi Kurikulum 2013 mata pelajaran Bahasa Indonesia SMA kelas XI dilihat dari cakupan ilmu kesastraan? 


\section{KAJIAN PUSTAKA}

\section{1) Kurikulum dan Pendidikan}

Dalam UU No. 20 Tahun 2003 tentang Sistem Pendidikan Nasional, Kurikulum memiliki pengertian yaitu seperangkat rencana dan pengaturan mengenai tujuan, isi, dan bahan pelajaran serta cara yang digunakan sebagai pedoman penyelenggaraan kegiatan pembelajaran untuk mencapai tujuan pendidikan tertentu.

Kurikulum dan pendidikan tentunya tak dapat dipisahkan, karena pengembangan kurikulum berlandaskan pada peraturan pendidikan atau yang lebih dikenal dengan Standar Nasional Pendidikan. Perangkat yang ada dalam kurikulum tentunya dibahas dalam Standar Nasional Pendidikan.

Dalam Undang-Undang Dasar Negara Republik Indonesia Tahun 1945 Pasal 31 ayat (1) menyebutkan bahwa setiap warga negara berhak mendapat pendidikan, dan ayat (3) menegaskan bahwa Pemerintah mengusahakan dan menyelenggarakan satu sistem pendidikan nasional yang meningkatkan keimanan dan ketakwaan serta akhlak mulia dalam rangka mencerdaskan kehidupan bangsa yang diatur dengan undang-undang.

Ada banyak Kurikulum yang sudah di tetapkan di Indonesia, diantaranya Kurikulum 1994, Kurikulum 2004 (KBK), Kurikulum 2006 atau yang lebih dikenal dengan nama Kurikulum Tingkat Satuan Pendid ik an (KTSP) dan Kurikulum 2013.

Kurikulum 2006 atau yang lebih dikenal dengan nama Kurikulum Tingkat Satuan Pendidikan (KTSP) dalam Standar Nasional Pendidikan (SNP) Pasal 1 ayat 15 dikemukakan bahwa Kurikulum Tingkat Satuan Pendidikan (KTSP) adalah kurikulum operasional yang disusun dan dilaksanakan oleh masing-masing satuan pendidikan. (Mulyasa, 2011:19)

Dalam dokumen ini dibahas standar isi sebagaimana dimaksud oleh Peraturan Pemerintah Nomor 19 Tahun 2005, yang secara keseluruhan mencakup:

a) Kerangka dasar dan struktur kurikulum yang merupakan pedoman dalam penyusunan kurikulum pada tingkat satuan pendidikan

b) Beban belajar bagi peserta didik pada satuan pendidikan dasar dan Menengah

c) Kurikulum tingkat satuan pendidikan yang akan dikembangkan oleh satuan pendidikan berdasarkan panduan penyusunan kurikulum sebagai bagian tidak terpisahkan dari stand ar isi

d) Kalender pendidikan untuk penyelenggaraan pendidikan pada satuan pendidikan jenjang pendidikan dasar dan menengah.

Sedangkan Kurikulum 2013 mulai diberlakukan pada tahun ajaran 2013/2014 memenuhi kedua dimensi tersebut. Hal ini sesuai dengan Permendikbud No. 59 Tahun 2014, Pasal 1 ayat 1-2 yaitu Kurikulum pada sekolah menengah atas/madrasah aliyah yang telah dilaksanakan sejak tahun ajaran 2013/2014 disebut 
Kurikulum 2013 Sekolah Menengah Atas/Madrasah Aliyah. Kurikulum 2013 Sekolah Menengah Atas/Madrasah Aliyah terdiri atas:

a) Kerangka Dasar Kurikulum;

b) Struktur Kurikulum;

c) Silabus; dan

d) Pedoman Mata Pelajaran.

\section{2) Taksonomi tujuan pembelajaran}

Dalam pelaksanaan kegiatan pembelajaran, tujuan pembelajaran dapat menjadi pegangan bagi para pelaksana pendidikan, karena tujuan pembelajaran merupaka bagian dari tujuan yang harus dicapai oleh peserta didik yang mengikuti kegiatan pembelajaran. Tujuan pembelajaran dirumuskan dalam bentuk Standar Kompetensi Lulusan, Standar Kompetensi, Kompetensi Dasar dan Indikator pembelajaran.

Tujuan pembelajaran dibedakan atas beberapa kategori, sesuai dengan perilaku yang menjadi sasarannya. Ada beberapa kategori tujuan pembelajaran, yang masingmasing memiliki perbedaan dan persamaan satu sama lain. Salah satu kategori tujuan pembelajaran yang terkenal yaitu Taksonomi Bloom yang dikeluarkan oleh Benyamin Samuel Bloom.

Bloom membedakan Taksonomi ke dalam tiga kategori atau biasa dikenal dengan "ranah" (terjemahaan dari domain). Pertama ranah kognitif yang terbagi lagi kedalam enam tingkatan yang dimaksud adalah Pengetahuan (Knowledge, C1), Pemahaman (Comprehension, C2), Penerapan (Application, C3), Analisis (Analysis, C4), Sintesis (Synthesis, C5), dan Evaluasi (Evaluation, C6). Kedua ranah afektif yang terbagi lagi kedalam lima tingkatan atau tataran, yaitu Penerimaan (Receiving, A1), Merespon (Responding, A2), Menilai (Valuing, A3), Mengorganisasi (Organization, A4), dan Karaterisasi Nilai (Characterization of by Values or Value Set, A5). Ketiga ranah psikomotor yang terbagi kedalam tujuh kategori yaitu persepsi (P1), kesiapan (P2), reaksi yang diarahkan (P3), reaksi natural (mekanisme) (P4), reaksi kompleks (P5), adaptasi (P6), dan kreativitas (P7).

\section{3) Keterampilan berbahasaan}

Dalam keterampilan berbahasa terdapat empat tingkatan keterampilan berbahasa yaitu menyimak, berbicara, membaca dan menulis.

Menurut Tarigan (2008:31), menyimak adalah suatu proses kegiatan mendengarkan lambang-lambang lisan dengan penuh perhatian, pemahaman, apresiasi, serta interpretasi untuk memperoleh informasi, menangkap isi atau pesan, serta memahami makna komunikasi yang telah disampaikan sang pembicara melalui ujaran atau bahasa lisan.

Menurut Tarigan (2008: 16), berbicara adalah kemampuan mengucapkan bunyibunyi artikulasi atau kata-kata untuk mengekspresikan, menyatakan atau menyampaikan pikiran, gagasan, dan perasaan. 
Menurut Hodgson (dalam Tarigan, 2008: 7) mengatakan bahwa, membaca adalah suatu proses yang dilakukan serta dipergunakan oleh pembaca untuk memperoleh pesan, yang hendak disampaikan oleh peulis melaluimedia kata-kata/ bahasa tulis

Menurut Tarigan (2008: 3-4), menulis merupakan suatu keterampilan berbahasa yang dopergunakan untuk berkomunikasi secara tidak langsung, tidak secara tatap muka dengan orang lain. Menulis merupakan suatu kegiatan yang produktif dan ekspresif. Dalam kegiatan menulis ini, peneliti haruslah terampil memanfaatkan grafolegi, struktur bahasa, dan kosa kata. Keterampilan menulis ini tidak akan datang seacar otoatis, tetapi harus melalui latihan dan praktik yang banyak teratur.

\section{4) Ilmu kebahasaan}

Dalam ilmu kebahasaan terdapat beberapa cabang ilmu yang termasuk kedalam cabang ilmu kebahasaan diantaranya yaitu fonologi, morfologi, sintaksis, dan semantik.

Menurut Pateda (1994), fonologi adalah ilmu yang mempelajari bunyi bahasa yang berfungsi dalam ujaran.

Menurut Ramlan (2009: 21),morfologi ialah bagian dari ilmu bahasa yang membicarakan atau yang mempelajari seluk-beluk bentuk kata serta pengaruh perubahan-perubahan bentuk kata terhadap golongan dan arti kata, atau dengan kata lain dapat dikatakan bahwa morfologi mempelajari seluk-beluk bentuk kata serta fungsi perubahan-perubahan bentuk kata itu, baik fungsi gramatik maupun fungsi semantik.

Menurut Ramlan (2005: 18), sintaksis secara langsung terambil dari bahasa Belanda syntaxis. Dalam bahasa Inggris digunakan istilah syntax. Sintaksis ialah bagian atau cabang dari ilmu bahasa yang mebicarakan seluk beluk wacana, kalimat, klausa, dan frase, berbeda dengan morfologi yang mebicarakan seluk-beluk kata dan morfem.

Kata semantik dalam bahasa Indonesia (Inggris: semantics) berasal dari bahasa Yunani sema (kata benda yang berarti "tanda" atau "lambang"). Semantik dapat diartikan sebagai ilmu tentang makna atau tentang arti. (Chaer, 2009: 2)

\section{5) Ilmu kesastraan}

Bentuk sastra dapat digolongkan menjadi tiga bentuk, yaitu puisi, prosa, dan drama. (dalam Sugiantomas : 2011). Jenis puisi dibagi menjadi 3 jenis yaitu puisi lama, baru dan modern.

Puisi lama terbagi atas mantra, bidal, pantun, talibun, gurindam, syair, seloka, madah, rubai, nazam, gazal. Puisi baru terdiri atas sajak terikat dan soneta. Sajak terikat terdiri atas Distichon (sajak dua seuntai), Terzina (tiga seuntai), Quatrain (empat seuntai), Quin (lima seuntai), Sextet (enam seuntai), Septina (enam seuntai) dan Stanza (tujuh seuntai). Sedangkan soneta adalah puisi baru yang terdiri dari empat belas baris. Puisi modern terbagi atas dua jenis yaitu puisi konvensional dan non konvensional. Puisi konvensional terdiri atas diaphan dan prismatis. Sedangkan puisi non konvensional terdiri atas puisi mantra, mbeling dan tipografi. 
Prosa lebih dekat dengan bahasa sehari-hari menurut Panuti Sudjiman (dalam Sugiantomas, 2012:60). Prosa ialah karya sastra dalam bentuk bahasa yang terurai tidak terikat oleh rima, ritma, jumlah baris dan sebagainya. Prosa dibagi menjadi dua; prosa imajinatif dan prosa non-imajinatif. Penggolongan prosa fiksi dapat dilakukan berdasarkan kurun waktu, gaya ungkap, isinya, dan unsur-unsurnya yang menonjol.

Berdasarkan kurun waktu, prosa fiksi terdiri dari dongeng, hikayat, cerita sejarah, cerpen, novel, novelet, riwayat hidup, dan kisah atau skema.

Kata drama berasal dari Yunani 'draomai' yang berarti 'berbuat', 'berlaku', atau 'suatu perbuatan'. Jenis drama itu sendiri dibagi menjadi dua yaitu drama tadisional dan drama modern. Drama tradisonal terbagi atas drama rakyat, klasik dan transisi. Sedangkan drama modern terdiri atas drama konvensional dan kontemporer. Drama dapat dikelompokan pada bentuk karya sastra, dan juga bukan karya sastra. Sebagai karya sastra, drama disebut sebagai bentuk cerita atau lakon yang tersusun dalam bentuk dialog baik bergaya puisi atau prosa yang mengandung pertentangan dramatik untuk pentas di atas panggung (berbentuk naskah drama).

\section{METODE PENELITIAN}

Penelitian ini menggunakan metode penelitian deskriptif kualitatif. Penelitian deskriptif kualitatif menurut Heryadi (2010:42), adalah metode penelitian yang digunakan penulis untuk menggambarkan suatu objek yang ada dan terjadi saat itu dalam rangka menjawab suatu permasalahan.

\section{HASIL PENELITIAN DAN PEMBAHASAN}

Pada standar Isi Kurikulum 2006, terdapat 4 Aspek yaitu Mendengarkan, Berbicara, Membaca dan Menulis. Sedangkan dalam standar Isi Kurikulum 2013, terdapat 4 aspek yaitu Sikap Spiritual, Sikap Sosial Pengetahuan dan Keterampilan. Dalam masing-masing Standar Isi Kurikulum tersebut tentunya memiliki kata kerja yang berbeda sesuai dengan aspeknya. Setelah dianalisis ternyata diperoleh hasil sebagai berikut:

Taksonomi Tujuan Pembelajaran yang terdapat pada SK dan KD dalam Standar Isi Kurikulum 2006 mata pelajaran bahasa Indonesia SMA kelas XI, setelah dianalisis melalui kata kerja operasional yang terdapat pada SK dan KD dalam Standar Isi Kurikulum 2006 mata pelajaran bahasa Indonesia SMA kelas XI, secara garis besar dapat disimpulkan bahwa, taksonomi tujuan pembelajaran pada ranah kognitif terdapat pada jenjang pengetahuan $(\mathrm{C} 1)$, jenjang pemahaman $(\mathrm{C} 2)$, jenjang penerapan (C3), jenjang analisa (C4), dan jenjang evaluasi (C6). Pada ranah afektif terdapat pada jenjang penerimaan (A1), jenjang responsif (A2), jenjang menilai (A3) dan 
jenjang mengorganisasi (A4). Pada ranah psikomor terdapat pada jenjang persepsi (P1) dan jenjang reaksi yang diarahkan (P3).

Taksonomi Tujuan Pembelajaran yang terdapat pada KI dan KD dalam Standar Isi Kurikulum 2013 mata pelajaran bahasa Indonesia SMA kelas XI wajib, secara garis besar dapat disimpulkan bahwa, taksonomi tujuan pembelajaran pada ranah kognitif terdapat pada jenjang pengetahuan (C1), jenjang pemahaman (C2), jenjang penerapan (C3), jenjang analisis (C4), jenjang sintesa (C5) dan jenjang evaluasi (C6). Pada ranah afektif yang terdapat pada jenjang penerimaan (A1), jenjang responsif (A2), jenjang menilai (A3), jenjang mengorganisasi (A4) dan jenjang karakterisasi nilai (A5). Pada ranah psikomotor mencakup jenjang kesiapan (P2), jenjang mekanisme (P4), jenjang adaptasi (P6) dan jenjang kreativitas (P7).

Jika dilihat secara keseluruhan Taksonomi Tujuan Pembelajaran yang terdapat pada SK dan KD dalam Standar Isi Kurikulum 2006 mata pelajaran bahasa Indonesia SMA kelas XI jika dilihat secara keseluruhan, ternyata lebih mendominasi pada ranah kognitif jenjang pemahaman (C2). Sedangkan Taksonomi Tujuan Pembelajaran yang terdapat pada KI dan KD dalam Standar Isi Kurikulum 2013 mata pelajaran bahasa Indonesia SMA kelas XI wajib, jika dilihat secara keseluruhan ternyata lebih mendominasi pada ranah Kognitif jenjang penerapan (C3). Berdasarkan analisis tersebut, maka dapat disimpulkan bahwa Taksonomi Tujuan.

Setelah ditelaah berdasarkan hasil analisis Ely Nuraliyah dan Sri Wulan, maka diperoleh data cakupan keterampilan berbahasa, ilmu kebahasaan dan ilmu kesastraan yang terdapat dalam Standar Isi Kurikulum 2006 dan Standar Isi Kurikulum 2013, maka diperoleh data sebagai berikut.

Jika dilihat berdasarkan cakupan keterampilan berbahasa dalam SKKD mata pelajaran bahasa Indonesia SMA kelas XI, yang lebih dominan adalah keterampilan berbahasa menulis. Sementara KIKD mata pelajaran bahasa Indonesia SMA kelas XI wajib, yang lebih dominan adalah keterampilan berbahasa menulis (menulis narasi, deskriptif, eksposisis dan argumentasi).

Cakupan ilmu kebahasaan dalam SKKD Kurikulum 2006 mata pelajaran bahasa Indonesia SMA kelas XI yang lebih mendominasi adalah ilmu kebahasaan semantik. Sementara KIKD Kurikulum 2013 mata pelajaran bahasa Indonesia SMA kelas XI wajib, cakupan ilmu kebahasaan fonologi (bunyi segmental dan bunyi supra segmental), morfologi (kata), sintaksis (kalimat), semantik (jenis makna, relasi makna, majas), dalam KIKD berfungsi sebagai penunjang dalam proses penyampaian informasi.

Cakupan ilmu kesastraan dalam SKKD Kurikulum 2006 mata pelajaran bahasa Indonesia SMA kelas XI dan KIKD Kurikulum 2013 mata pelajaran bahasa Indonesia SMA kelas XI wajib, lebih dominan pada kesastraan drama (film/drama).

\section{SIMPULAN}


Standar Isi Kurikulum 2006 mata pelajaran bahasa Indonesia SMA kelas XI, jika dilihat berdasarkan taksonomi tujuan pembelajaran ternyata lebih mendominasi pada ranah kognitif jenjang pemahaman (C2). Sedangkan Standar Isi Kurikulum 2013 mata pelajaran bahasa Indonesia SMA kelas XI, jika dilihat berdasarkan taksonomi tujuan pembelajaran ternyata lebih mendominasi pada ranah kognitif jenjang penerapan (C3). Berdasarkan hal tersebut, maka dapat disimpulkan bahwa taksonomi tujuan pembelajaran yang terdapat pada SK dan KD dalam Standar Isi Kurikulum 2006 dan pada KI dan KD dalam Standar Isi Kurikulum 2013 mata pelajaran bahasa Indonesia SMA kelas XI, ternyata sama-sama lebih mendominasi pada ranah kognitif, namun yang membedakan hanyalah cakupan jenjang ranah kognitifnya saja.

Standar Isi Kurikulum 2006 dan Standar Isi Kurikulum 2013 mata pelajaran bahasa Indonesia SMA kelas XI, jika dilihat berdasarkan cakupan keterampilan berbahasa ternyata sama-sama mendominasi kedalam keterampilan berbicara (resmi dan tidak resmi) dan menulis (menulis narasi, menulis deskripsi, menulis eksposisi, dan menulis argumentasi).

Sedangkan Cakupan ilmu kebahasaan dalam Standar Isi Kurikulum 2006 mata pelajaran bahasa Indonesia SMA kelas XI yang lebih mendominasi adalah ilmu kebahasaan semantik. Sementara cakupan ilmu kebahasaan dalam Standar Isi Kurikulum 2013 mata pelajaran bahasa Indonesia SMA kelas XI wajib, mencakup ilmu kebahasaan fonologi (bunyi segmental dan bunyi supra segmental), morfologi (kata), sintaksis (kalimat), semantik (jenis makna, relasi makna, majas), dalam KIKD berfungsi sebagai penunjang dalam proses penyampaian informasi.

Standar Isi Kurikulum 2006 dan Standar Isi Kurikulum 2013 mata pelajaran bahasa Indonesia SMA kelas XI, jika dilihat berdasarkan ilmu kesastraan ternyata sama-sama lebih dominan pada kesastraan drama (film/drama).

\section{DAFTAR PUSTAKA}

Ahyadi, Didi. (2011). Linguistik Umum. Kuningan. Universitas Kuningan.

Arifin, E. Zaenal dan S. Amran Tasai. (2009). Cermat Berbahasa Indonesia. Jakarta: AKAPRES.

Chaer, Abdul.(2009). Fonologi Bahasa Indonesia. Jakarta: Rineka Cipta. .(2009). Pengantar Semantik Bahasa Indonesia. Jakarta:Rineka Cipta.

Hamalik, Oemar. (2010). Kurikulum dan Pembelajaran. Jakarta: Bumi Aksara. 
Heryadi, Dedi. (2010). Metode Penelitian Pendidikan Bahasa. Bandung: Pustaka Billah.

Hidayat, Sholeh. (2013). Pengembangan Kurikulum Baru. Bandung: Remaja Rosdakarya.

IKAPI.(2009). Undang-Undang Republik Indonesia tentang SISDIKNAS (Sistem Pendidikan Nasional). Bandung: Fokusmedia.

J.Waluyo, Herman. (1995). Teori dan Apresiasi Puisi. Jakarta: Erlangga.

Keraf, Gorys. (1984). Tata Bahasa Indonesia.Jakarta: Nusa Indah.

Kosasih, Engkos dan Hermawan, Wawan. (2012). Bahasa Indonesia (Berbasis Kepenulisan Karya Ilmiah dan Jurnal). Bandung: CV. Thursina.

Mulyasa, E. (2011).Kurikulum Tingkat Satuan Pendidikan. Bandung: Remaja.

Muslich, Masnur. (2012). Fonologi Bahasa Indonesia: Tinjauan Deskriptif Sistem Bunyi Bahasa Indonesia. Jakarta: Bumi Aksara.

Mutiadi, Ahmad Dedi. (2012). Menyimak\&Pengajarannya. Kuningan: Universitas Kuningan.

Muzamiroh, Mida Latifatul. (2013). Kupas Tuntas Kurikulum 2013. Kata Pena.

Nurgiantoro, Burhan. (2010). Penilaian Pembelajaran Bahasa. Yogyakarta: BEFE-Yogyakarta.

Pateda, Mansoer. (1994). Linguistik (SebuahPengantar). Bandung: Angkasa.

Pidarta, Made. (2007). Landasan Pendidikan (Stimulus Pendidik Bercorak Indonesia.Jakarta: Rineka Cipta.

Ramlan. (2005). Sintaksis. Yogyakarta: CV. Karyono.

_ (2009). Morfologi: Suatu Tinjauan Deskrptif. Yogyakarta: CV. Karyono.

Sanjaya, Wina. (2008). Kurikulum Pembelajaran. Jakarta: Kencana. . (2013). Kurikulum 2013. Jakarta: Kencana. 
Sugiantomas, Aan. (2011). Langkah Awal Menuju Apresiasi Sastra. Kuningan: Universitas Kuningan.

. (2012). Kajian Prosa Fiksi (Materi Perkuliahan) Kuningan: Universitas Kuningan.

Suryabrata, Sumadi. (2011). Metodologi Penelitian. Jakarta: Rajawali Pers

Tarigan, Henry Guntur. (2008). Membaca Sebagai Suatu Keterampilan Berbahasa. Bandung: Angkasa.

Bandung: Angkasa.

(2009). Pengajaran Sintaksis. Bandung: Angkasa.

TIM Penyusun. (2008). Kamus Bahasa Indonesia. Jakarta:Pusat Bahasa Departemen Pendidikan Nasional

Ullmann, Stephen. (2012). Pengantar Semantik. Yogyakarta:Pustaka Belajar.

Nuraliyah, Ely. (2012). “Analisis Sk Dan Kd Pada Standar Isi Mata Pelajaran Bahasa Indonesia di SMA Berdasarkan Keterampilan Berbahasa, Ilmu Kebahasaan, Dan Ilmu Kesastraan (Sebuah Analisis Isi SK dan KD Mendengarkan, Berbicara, Membaca, dan Menulis)". Skripsi pada FKIP Universitas Kuningan: tidak diterbitkan.

Wigunawa, Kemis. (2014). Analisis Buku Teks Bahasa Indonesia Kelas XI SMA Sekabupaten Kuningan Dalam Menjabarkan SK/KD Dilihat Dari Ilmu Kebahasaan dan Kesastraan Indonesia. Skripsi pada FKIP Universitas Kuningan: tidak diterbitkan.

Wulan, Sri. (2014). Cakupan Ilmu Keterampilan Bebahasa, Ilmu Kebahasaan dan Ilmu Kesastraan dalam KI serta KD Pada Standar Isi SMA Kelas XI Kurikulum 2013 Mata Pelajaran Bahasa Indonesia Wajib dan Peminatan. Skirpsi pada FKIP Universitas Kuningan: tidak diterbitkan.

Gunawan, Imam dan Palupi, A.R. (2014). 'Revisi Ranah Kognitif: Kerangka Landasan Untuk Pembelajaran, Pengajaran dan Penilaian" dalam Taksosomi Bloom [online], 25 halaman.

Tersedia: http://ejournal.ikippgrimadiun.ac.id/id/mode/405.html [13 Januari 2015] 
$\mathrm{P}$

Sudrajat, Akhmad. (2014). Permendikbud Kurikulum [online]. Tersedia: http://akhmadsudrajat.files. wordpress.com/2013/06/07-a-salinanpermendikbud-no-69-th-2013-ttg-ttg-kd-dan-struktur-kurikulum-sma-ma.pdf [10 Desember 2014]

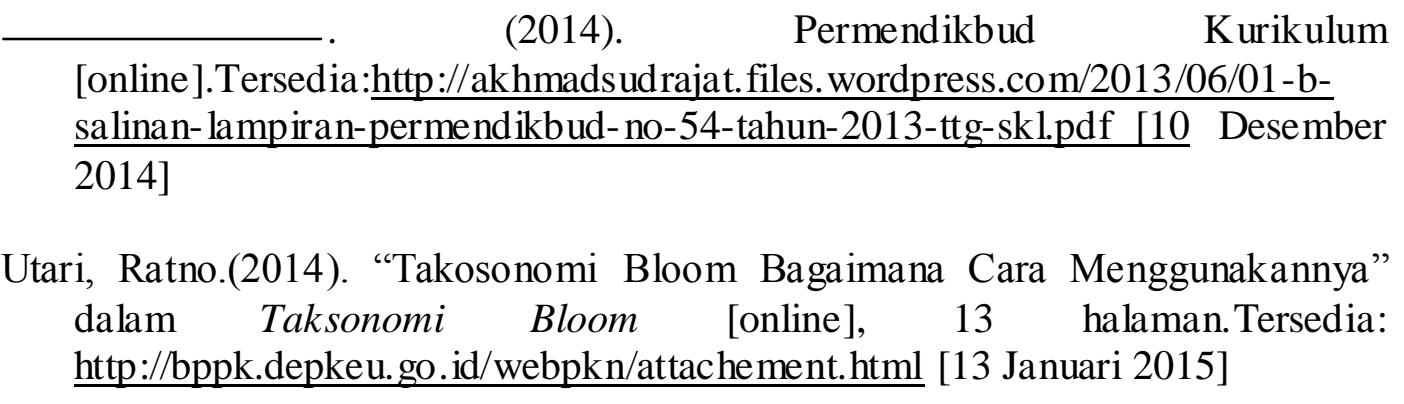

